\title{
STAB1 wt Allele
}

National Cancer Institute

\section{Source}

National Cancer Institute. STAB1 wt Allele. NCI Thesaurus. Code C159509.

Human STAB1 wild-type allele is located in the vicinity of 3p21.1 and is approximately 29 $\mathrm{kb}$ in length. This allele, which encodes stabilin-1 protein, plays a role in cell-cell signaling and binding to both bacteria and acetylated low density lipoprotein particles. 